\title{
HUBUNGAN METODE PEMBELAJARAN EXAMPLE NON-EX- AMPLE TERHADAP KETERAMPILAN MENULIS KARANGAN MATA PELAJARAN BAHASA INDONESIA SISWA MI MA' ARIF KARANGANYAR KABUPATEN MAGELANG
}

\author{
Ahwy Oktradiksa ${ }^{1)}$, Lya Isna Anirofa ${ }^{2)}$ \\ Universitas Muhammadiyah Magelang \\ email: ahwy@,ummgl.ac.id, lyaisnaanirofa@gmail.com
}

Naskah diterima : 23 Januari 2017, direvisi : 21 Februari 2017, disetujui : 2 Maret 2017

\begin{abstract}
Penelitian ini bertujuan untuk mengetahui hubungan penggunaan metode pembelajaran Example Non-Example terhadap keterampilan menulis karangan dalam mata pelajaran bahasa Indonesia siswa MI Ma'arif Karanganyar Kabupaten Magelang. Penelitian ini merupakan penelitian kuantitatif. Populasi penelitian ini meliputi siswa MI Ma'arif Karanganyar Kabupaten Magelang berjumlah 108 siswa. Adapun sampel penelitian ini berjumlah 18 siswa kelas $\mathrm{V}$ dengan teknik simple random sampling. Pengumpulan data diperoleh dengan teknik angket, observasi, wawancara, dan dokumentasi, sedangkan untuk menganalisis data dilakukan analisis kuantitatif dengan statistik. Untuk mengetahui hubungan penggunaan metode pembelajaran Example Non-Example terhadap keterampilan menulis karangan dalam mata pelajaran bahasa Indonesia siswa MI Ma'arif Karanganyar Kabupaten Magelang menggunakan bantuan program IBM SPSS Statistic 21 for windows. Hasil penelitian menunjukkan bahwa penggunaan metode pembelajaran Example Non-Example di MI Ma'arif Karanganyar Kabupaten Magelang dalam kategori cukup baik. Hal tersebut dapat dilihat dari nilai rata-rata 17,7 atau 18 yang termasuk dalam kategori cukup baik. Kemampuan keterampilan menulis masuk dalam kategori baik, hal tersebut dapat dilihat dari nilai rata-rata 23,5 atau 24 yang termasuk dalam kategori baik. Analisis korelasi product moment diperoleh nilai rxy hitung sebesar 0,735. Hasil tersebut menunjukkan Ho ditolak dan Ha diterima, yaitu ada hubungan penggunaan metode pembelajaran Example Non-Example terhadap keterampilan menulis karangan mata pelajaran bahasa Indonesia siswa kelas V MI Ma'arif Karanganyar Kabupaten Magelang.
\end{abstract}


Keyword : Metode Example-Non Example, Keterampilan Menulis, Madrasah Ibtidaiyah

Pengutipan: Oktradiksa, Ahwy., Anirofa, Lya Isna. (2017). Hubungan Metode Pembelajaran Example Non-Example terhadap Keterampilan Menulis Karangan Mata Pelajaran Bahasa Indonesia Siswa Ma'arif Karanganyar Kabupaten Magelang. JMIE: Journal of Madrasah Ibtidaiyah Education, 1(1), 2017, 28-45. sd.v1i1.23.

\section{PENDAHULUAN}

Belajar merupakan proses interaksi terhadap semua situasi yang ada di sekitar individu. Kegiatan pembelajaran dilakukan oleh dua orang perilaku yaitu guru dan siswa. Perilaku guru adalah mengajar dan perilaku siswa adalah belajar. Perilaku mengajar dan belajar tersebut terkait dengan bahan pembelajaran. Pembelajaran merupakan suatu sistem yang terdiri atas berbagai komponen yang saling berhubungan satu sama lain. Komponen tersebut meliputi tujuan, materi, metode, dan evaluasi. Guru harus mampu menentukan metode pembelajarn yang digunakan dalam kegiatan pembelajaran.

Guru pada hakikatnya merupakan tenaga kependidikan yang memiliki tanggung jawab kemanusiaan, khususnya berkaitan dengan proses pendidikan generasi penerus bangsa. Melalui kompetensi profesionalnya, guru harus mampu mewujudkan langkah-langkah pembelajaran inovatif, progresif, dan kreatif sehingga proses belajar mengajar dapat bermakna dan mudah tersampaikan. Hal ini menuntut perubahan penggunaan metode pembelajaran di MI Ma'arif Karanganyar khususnya dalam kegiatan menulis karangan mata pelajaran bahasa indonesia yang masih menggunakan cara konvensional khususnya. Cara konvensional yang digunakan guru bahasa indonesia membuat siswa terlibat pasif untuk mengemukakan ide atau gagasan yang baru sesuai dengan pengetahuannya.

Setiap keterampilan berbahasa erat sekali berhubungan dengan tiga keterampilan lainnya dengan cara yang beraneka ragam. Dalam memperoleh keterampilan berbahasa, kita biasanya melalui suatu hubungan urutan yang teratur: mula-mula pada masa kecil, kita belajar menyimak bahasa, kemudian berbicara, sesudah itu kita belajar membaca dan menulis. Menyimak dan berbicara kita pelajari sebelum memasuki sekolah. Keempat keterampilan tersebut pada dasarnya merupakan satu kesatuan, merupakan catur-tunggal (Tarigan, 2008: 1). Selanjutnya setiap keterampilan itu erat pula berhubungan dengan proses-proses yang mendasari bahasa. Bahasa seseorang mencerminkan pikirannya. Semakin terampil seseorang berbahasa, semakin cerah dan jelas jalan pikirannya. Keterampilan hanya dapat diperoleh dan dikuasai dengan jalan praktik dan banyak pelatihan. Melatih keterampilan berbahasa berarti pula melatih katerampilan berfikir.

Menulis merupakan suatu keterampilan berbahasa yang dipergunakan untuk berkomunikasi secara tidak langsung, tidak secara tatap muka dengan orang lain. 
Dalam kegiatan menulis, penulis harus terampil memanfaatkan grafologi, struktur bahasa, dan kosa kata. Keterampilan menulis ini tidak akan datang secara otomatis, tetapi harus melalui latihan dan praktik yang banyak dan teratur (Tarigan, 2008: 4). Dalam kehidupan modern ini, jelas bahwa keterampilan menulis sangat dibutuhkan. Melalui bahasa tulis, ternyata kita dapat lebih banyak menerima pengetahuan yang bermacam corak, dan sejenisnya dan mengenal komunikasi yang lebih luas ternyata membutuhkan banyak bahasa tulis daripada bahasa tutur atau bahasa ujaran (Sri Hastuti, 1984: 98) .

Pembelajaran menulis disekolah dasar didasarkan pada interaksi antara dua pendekatan, pendekatan yang berorientasi pada proses dan berorientasi pada produk. Oleh karena itu, evaluasi yang dilakukan juga berupa evaluasi proses dan evaluasi produk. Penilaian dan metode pembelajaran yang digunakan oleh guru dalam pembelajaran menulis karangan sangat diperlukan terutama untuk melihat proses dan hasil kegiatan menulis siswa.

Hasil observasi yang telah dilakukan oleh peneliti, penerapan metode Example Non-Example melalui media gambar digunakan untuk membantu peserta didik berpikir kreatif dan menuangkan gagasannya dalam bentuk tulisan. Melalui proses pembelajaran yang dinamis diharapkan akan tercipta suatu bentuk komunikasi antar peserta didik, sehingga suasana pembelajaran terhindar dari kejenuhan. Dalam keterampilan menulis, seorang penulis (siswa) perlu mengunakan kaidah bahasa indonesia yang benar agar mempermudah pembaca untuk memahami tulisan tersebut.

Adapun tujuan yang ingin dicapai dalam penelitian ini adalah:

a. Mengetahui ketepatan penggunaan metode pembelajaran Example NonExample yang digunakan oleh guru kelas V di MI Ma'arif Karanganyar Kabupaten Magelang.

b. Mengetahui kemampuan keterampilan menulis karangan siswa kelas V di MI Ma'arif Karanganyar Kabupaten Magelang.

c. Mengetahui hubungan antara metode pembelajaran Example Non-Example dalam kemampuan keterampilan menulis karangan siswa kelas V MI Ma'arif Karanganyar Kabupaten Magelang.

\section{KAJIAN TEORI Metode Pembelajaran}

Metode pembelajaran adalah cara-cara atau teknik penyajian bahan pelajaran yang akan digunakan oleh guru pada saat menyajikan bahan pelajaran, baik secara individual atau secara kelompok. Agar tercapainya tujuan pembelajaran yang telah dirumuskan, seorang guru harus mengetahui berbagai metode. Dengan memiliki pengetahuan mengenai sifat berbagai metode maka seorang guru akan lebih mudah menetapkan metode yang paling sesuai dengan situasi dan kondisi. Penggunaan 
metode mengajar sangat bergantung pada tujuan pembelajaran.

Syarat- syarat yang harus diperhatikan seorang guru dalam penggunaan metode pembelajaran adalah sebagai berikut:

1) Metode yang dipergunakan harus dapat membangkitkan motif, minat atau gairah belajar siswa.

2) Metode yang digunakan dapat merangsang keinginan siswa untuk belajar lebih lanjut, seperti melakukan inovasi dan ekspotasi.

3) Metode yang digunakan harus dapat memberikan kesempatan bagi siswa untuk mewujudkan hasil karya.

4) Metode yang digunakan harus dapat menjamin perkembangan kegiatan kepribadian siswa.

5) Metode yang digunakan harus dapat mendidik murid dalam teknik belajar sendiri dan cara memperoleh pengetahuan melalui usaha pribadi.

6) Metode yang digunakan harus dapat menanamkan dan mengembangkan nilainilai dan sikap siswa dalam kehidupan sehari-hari.

\section{Metode Pembelajaran Example Non-Example}

Miftahul Huda, dalam bukunya Model-Model Pengajaran Dan Pembelajaran: Isu-Isu Metodis Dan Paradigmatis, 2015), Example Non-Example merupakan strategi pembelajaran yang menggunakan gambar sebagai media untuk menyampaikan materi pelajaran. Metode ini bertujuan mendorong siswa untuk belajar berfikir kritis dengan memecahkan permasalahan-permasalahan yang termuat dalam contoh-contoh gambar yang disajikan. Penggunaan media gambar dirancang agar siswa dapat menganalisis gambar tersebut untuk kemudian dideskripsikan secara singkat perihal isi dari sebuah gambar. Dengan demikian, metode ini menekankan pada konteks analisis siswa. Gambar yang digunakan dalam metode ini dapat ditampilkan melalui OHP, proyektor, atau yang paling sederhana, yaitu poster. gambar ini haruslah jelas terlihat meski dari jarak jauh, sehingga siswa yang berada di bangku belakang dapat juga melihatnya dengan jelas.

Metode Example Non-Example juga ditujukan untuk mengajarkan siswa dalam belajar memahami dan menganalisis sebuah konsep. Konsep pada umumnya dipelajari melalui dua cara: pengamatan dan definisi. Example Non-Example adalah metode yang dapat digunakan untuk mengajarkan definisi konsep.

Langkah-langkah penerapan strategi pembelajaran Example Non-Example dapat dilakukan sebagai berikut:

1) Guru mempersiapkan gambar-gambar sesuai dengan tujuan pembelajaran.

2) Guru menempelkan gambar di papan atau ditayangkan lewat OHP.

3) Guru membentuk kelompok-kelompok yang masing-masing terdiri dari 2-3 siswa. 
4) Guru memberi petunjuk dan memberi kesempatan kepada setiap kelompok untuk memperhatikan dan/ atau menganalisis gambar.

5) Mencatat hasil diskusi dari analisis gambar pada kertas.

6) Memberi kesempatan bagi tiap kelompok untuk membacakan hasil diskusinya.

7) Berdasarkan komentar atau hasil diskusi siswa, guru menjelaskan materi sesuai tujuan yang ingin dicapai.

8) Penutup.

\section{Keterampilan Menulis Karangan}

Menurut Kundharu Saddhono (Syafi'e, 1993: 52), keterampilan menulis merupakan salah satu bentuk keterampilan berbahasa yang sangat penting bagi pembaca, di samping keterampilan menyimak, berbicara, dan membaca, baik selama mereka mengikuti pendidikan di berbagai jenjang dan jenis sekolah maupun dalam kehidupannya nanti di masyarakat. Pembelajaran menulis mempunyai kedudukan yang sangat strategis dalam pendidikan dan pengajaran. Keterampilan menulis harus dikuasai oleh anak sedini mungkin dalam kehidupannya di sekolah.

Menulis dapat didefinisikan sebagai suatu kegiatan penyampaian pesan (komunikasi) dengan menggunakan bahasa tulis sebagai alat medianya. Pada dasarnya menulis itu, bukan hanya berupa melahirkan pikiran atau perasaan saja, melainkan juga merupakan pengungkapan ide, pengetahuan, ilmu, dan pengalaman hidup seseorang dalam bahasa tulis. Oleh karena itu, menulis bukanlah merupakan kegiatan yang sederhana dan tidak perlu dipelajari, tetapi justru dikuasai.

Sebagai proses, menulis merupakan serangkaian aktivitas (kegiatan) yang terjadi dan melibatkan beberapa fase (tahap) yaitu fase pramenulis (persiapan), penulisan (pengembangan isi karangan), dan pascapenulisan (telaah dan revisi atau penyempurnaan tulisan). Menulis, di samping sebagai proses, menulis itu juga merupakan suatu kegiatan yang komplek. Kegiatan menulis merupakan kegiatan yang sangat kompleks karena melibatkan cara berpikir yang teratur dan berbagai persyaratan yang berkaitan dengan teknik penulisan, antara lain:

1) Adanya penguasaan gagasan

2) Penggunaan kalimat yang jelas dan efektif

3) Paragraf disusun dengan baik

4) Penerapan kaidah ejaan yang benar

5) Penguasaan kosakata yang memadai

\section{Karangan}

Suatu tulisan atau karangan dapat dilihat dari segi bahasa yang digunakan, isi tulisan/ karangan, dan bentuk atau cara penyajiannya. Bahasa yang digunakan dalam tulisan/ karangan itu, apakah bahasa yang sulit, sederhana, mudah, dan lancar. Sebelum menulis karangan kita harus memperhatikan beberapa langkah 
berikut ini:

1) Penentuan tema

2) Penulisan judul

3) Pembuatan kerangka karangan

4) Pengembangan kerangka karangan menjadi paragraf-paragraf yang padu.

Satuan bagian karangan yang digunakan untuk mengungkapkan sebuah gagasan dalam bentuk untaian kalimat disebut paragraf atau alinea. Berdasarkan pengertian itu, paragraf dapat disebut sebagai untaian kalimat yang berisi sebuah gagasan dalam karangan. Dengan pengertian itu, sejalan dengan konsep untaian kalimat, paragraf yang ideal terdiri atas sejumlah kalimat. Kalimat yang baik adalah kalimat yang penulisannya sesuai dengan kaidah bahasa indonesia yang baik dan benar sesuai dengan EYD (Ejaan Yang Disempunakan). Dalam kegiatan menulis karangan, penggunaan diksi (pilihan kata) dan struktur kalimat juga harus diperhatikan

\section{Jenis-jenis karangan}

Karangan dapat disajikan dalam lima bentuk atau ragam wacana, diantaranya adalah sebagi berikut:

1) Deskripsi (pemerian), adalah ragam wacana yang melukiskan atau menggambarkan sesuatu berdasarkan kesan-kesan dari pengamatan, pengalaman, dan perasaan penulisnya. Sasarannya adalah menciptakan atau memungkinkan terciptanya imajinasi (daya khayal) pembaca sehingga dia seolah-olah melihat, mengalami, dan merasakan sendiri apa yang dialami penulisnya.

2) Narasi (penceritaan atau pengisahan) adalah ragam wacana yang menceritakan proses kejadian suatu peristiwa. Sasarannya adalah memberikan gambaran yang sejelas-jelasnya kepada pembaca mengenai fase, urutan, langkah, atau rangkaian terjadinya sesuatu hal.

3) Eksposisi(paparan)adalahragamwacanayangdimaksudkanuntuk menerangkan, menyampaikan, atau menguraikan sesuatu hal yang dapat memperluas atau menambah pengetahuan dan pandangan pembacanya. Sasarannya adalah menginformasikan sesuatu tanpa ada maksud mempengaruhi pikiran, perasaan, dan sikap pembacanya. fakta dan ilustrasi yang disampaikan penulis sekadar memperjelas apa yang akan disampaikannya.

4) Argumentasi (pembahasan atau pembuktian) adalah ragam wacana yang dimaksudkan untuk meyakinkan pembaca mengenai kebenaran yang disampaikan oleh penulisnya. Karena tujuannya akan secara logis, kritis, dan sistematis bukti-bukti yang dapat memperkuat keobjektifan dan kebenaran 
yang disampaikannya sehingga dapat menghapus konflik dan keraguan pembaca terhadap pendapat penulis. Corak karangan seperti ini adalah hasil penilaian, pembelaan, dan timbangan buku.

5) Persuasi adalah ragam wacana yang ditujukan untuk mempengaruhi sikap dan pendapat pembaca mengenai sesuatu yang disampaikan oleh penulisnya. Berbeda dengan argumentasi yang pendekatannya bersifat rasional dan diarahkan untuk mencapai kebenaran, sedangkan persuasi lebih menggunakan pendekatan emosional. Persuasi juga menggunakan fakta. hanya saja, dalam persuasi bukti-bukti itu digunakan seperlunya atau kadang-kadang dimanipulasi untuk menimbulkan kepercayaan pada diri pembaca bahwa apa yang disampaikan si penulis itu benar.

\section{METODE PENELITIAN Desain Penelitian}

Penelitian ini merupakan jenis penelitian suvey dengan data yang akurat tentang hubungan metode pembelajaran Example Non-Example dalam keterampilan menulis karangan mata pelajaran bahasa Indonesia.

\section{Instrumen dan Teknik Pengumpulan data}

Teknik pengumpulan data yang dilakukan yaitu menggunakan metode angket, wawancara, dokumentasi, observasi.

\section{Teknis Analisa Data}

Yaitu menggunakan teknik analisis kuantitatif yaitu dengan analisis uji hipotesis product moment. Analisis ini digunakan untuk menghitung skor masingmasing variabel terpisah, sehingga diketahui ciri-ciri masing-masing variabel.

\section{HASIL DAN PEMBAHASAN}

Berikut deskripsi data penelitian mengenai hubungan penggunaan metode pembelajaran Example Non-Example terhadap keterampilan menulis karangan dalam mata pelajaran bahasa Indonesia siswa MI Ma'arif Karanganyar Kabupaten Magelang sebagai berikut:

\section{Metode pembelajaran Example Non Example di MI Ma' arif Karanganyar}

Variabel metode pembelajaran Example Non Example mempunyai jumlah sampel 18 responden. Pengumpulan data yang digunakan untuk variabel metode pembelajaran Example Non Example menggunakan teknik angket tertutup dengan 
jumlah pertanyaan sebanyak 10 item dengan tiga alternatif jawaban yang telah disediakan. Penyusunan angket ini berdasarkan landasan teori pada bab dua kemudian disusun kisi-kisi angketnya sebagaimana sudah tercantum pada bab tiga. Adapun hasil jawaban responden berdasarkan indikator variabel dapat dilihat dalam tabel sebagai berikut:

\section{Tabel 4.1}

Data Hasil Jawaban Responden Tentang Metode Pembelajaran Example Non Example MI Ma'arif Karanganyar

\begin{tabular}{|c|c|c|c|c|c|}
\hline \multirow[b]{2}{*}{ No } & \multirow[b]{2}{*}{ Indikator } & \multirow{2}{*}{$\begin{array}{c}\text { Nomer } \\
\text { Butir An- } \\
\text { gket }\end{array}$} & \multicolumn{3}{|c|}{ Skor } \\
\hline & & & 1 & 2 & 3 \\
\hline \multirow{3}{*}{1} & \multirow{3}{*}{$\begin{array}{l}\text { Penggunaan metode Example Non-Example yang } \\
\text { mendukung isi bahan pelajaran. }\end{array}$} & 2 & 3 & 8 & 7 \\
\hline & & 3 & 3 & 1 & 14 \\
\hline & & 10 & 2 & 3 & 13 \\
\hline \multirow{2}{*}{2} & \multirow{2}{*}{$\begin{array}{l}\text { Efisiensi metode pembelajaran Example Non-Exam- } \\
\text { ple. }\end{array}$} & 6 & 2 & 5 & 11 \\
\hline & & 8 & 2 & 7 & 9 \\
\hline \multirow{2}{*}{3} & \multirow{2}{*}{$\begin{array}{l}\text { Kemampuan guru dalam menggunakan metode } \\
\text { Example Non-Example. }\end{array}$} & 5 & 2 & 5 & 11 \\
\hline & & 7 & 0 & 3 & 15 \\
\hline 4 & $\begin{array}{l}\text { Ketersediaan waktu dalam penggunaan metode Ex- } \\
\text { ample Non-Example. }\end{array}$ & 4 & 2 & 4 & 12 \\
\hline \multirow{2}{*}{5} & \multirow{2}{*}{$\begin{array}{l}\text { Penggunaan metode Example Non-Example sesuai } \\
\text { dengan taraf berfikir siswa. }\end{array}$} & 1 & 1 & 3 & 14 \\
\hline & & 9 & 3 & 2 & 13 \\
\hline
\end{tabular}

\section{Keterampilan Menulis Karangan MI Ma' arif Karanganyar}

Variabel keterampilan menulis karangan mempunyai jumlah sampel 18 responden. Pengumpulan data yang digunakan untuk variabel keterampilan menulis karangan menggunakan teknik angket tertutup dengan jumlah pertanyaan sebanyak 10 item dengan tiga alternatif jawaban yang telah disediakan. Penyusunan angket ini berdasarkan landasan teori pada bab dua kemudian disusun kisi-kisi angketnya sebagaimana sudah tercantum pada bab tiga. Adapun hasil jawaban responden berdasarkan indikator variabel dapat dilihat dalam tabel sebagai berikut:

\section{Tabel 4.2}

Data Hasil Jawaban Responden Tentang Keterampilan Menulis Karangan Mata Pelajaran Bahasa Indonesia Siswa MI Ma’arif Karanganyar

\begin{tabular}{llccccc}
\hline No & \multicolumn{1}{c}{ Indikator } & $\begin{array}{c}\text { Nomer } \\
\text { Butir An- } \\
\text { gket }\end{array}$ & $\mathbf{1}$ & $\mathbf{2}$ & $\mathbf{3}$ \\
\hline 1 & $\begin{array}{l}\text { Kekonsistenan } \\
\text { huruf pada tulisan. }\end{array}$ & bentuk/ukuran/porsi & 1 & 1 & 3 & 14 \\
2 & $\begin{array}{l}\text { Terdapat jarak tulisan antar kata. } \\
2\end{array}$ & 2 & 2 & 3 & 13
\end{tabular}




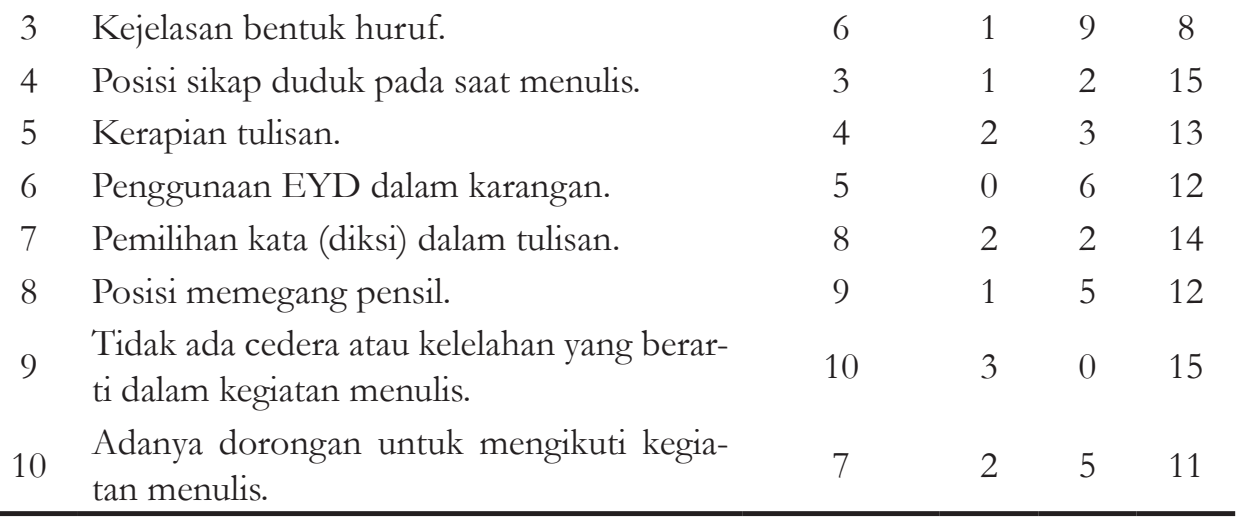

\section{Analisis Data Penelitian}

\section{1) Metode Pembelajaran Example Non Example di MI Ma'arif Karanganyar}

Setelah dibuat statistik deskripsi tiap variabel, hasil jawaban responden variabel penggunaan metode pembelajaran Example Non Example secara keseluruhan kemudian dikategorikan menjadi tiga yaitu setuju, kurang setuju, tidak setuju. Pembagian kategori menggunakan rumus interval kelas yaitu nilai tertinggi ideal dikurangi nilai terendah ideal ditambah satu kemudian dibagi jumlah kelas.

Untuk mencari nilai tertinggi ideal yaitu jumlah angket dikalikan nilai jawaban tertinggi 30 dari jumlah angket 10x3. Sedangkan nilai ideal terendah yaitu hasil dari jumlah angket 10 dikalikan nilai jawaban terendah 10x1. Adapun rumusan tersebut antara lain:

$$
\begin{gathered}
\text { Interval }=\frac{(\text { nilai tertinggi }- \text { nilai terendah })+1}{\text { jumlah kelas }} \\
\frac{(30-10)+1}{3}=\frac{21}{3}=7
\end{gathered}
$$

Adapun hasil klasifikasi jawaban responden dapat dilihat dari tabel berikut:

\section{Tabel 4.3}

Kategori Variabel Metode Pembelajaran Example Non Example

\begin{tabular}{ccccc}
\hline No & Nilai & Jumlah & Presentase & Kriteria \\
\hline 1 & $10-16$ & 0 & $0 \%$ & Kurang \\
2 & $17-23$ & 3 & $17 \%$ & Cukup \\
3 & $24-30$ & 15 & $83 \%$ & Baik \\
Jumlah & & 18 & $100 \%$ & \\
\hline
\end{tabular}


Berdasarkan distribusi frekuensi jawaban di atas tampak bahwa dari 18 responden, 83\% penggunaan metode pembelajaran Example Non Example yang menimbulkan kemampuan keterampilan menulis karangan yang diterapkan dalam proses pembelajaran. Distribusi jawaban responden tersebut dapat digambarkan sebagai berikut:

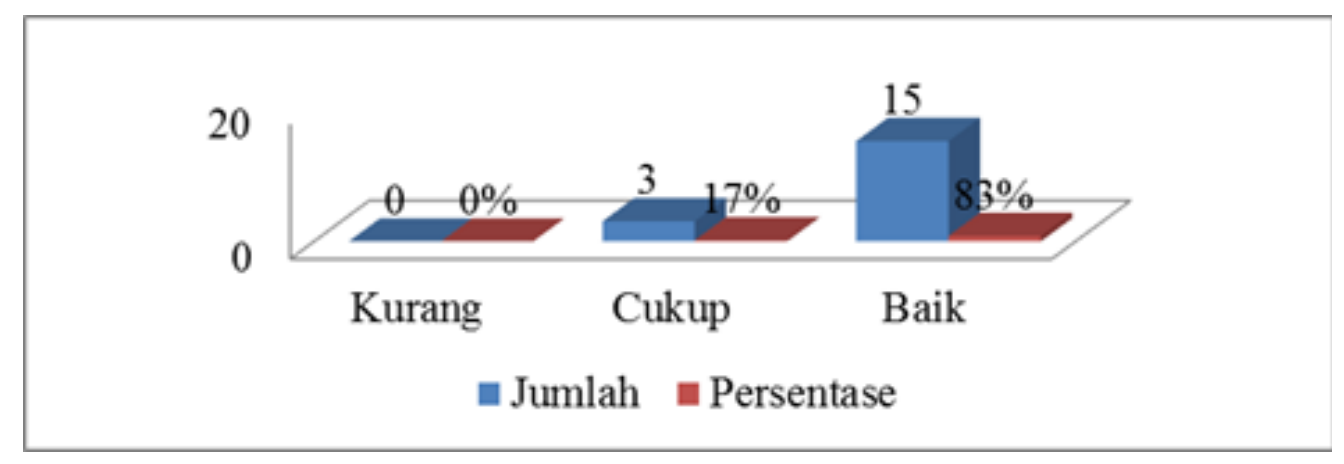

Grafik 4.1

Grafik Metode Pembelajaran Example Non Example

Dari data hasil jawaban responden berdasarkan indikator variabel metode pembelajaran Example Non Example dalam tabel 4.2 diadakan presentase jawaban terhadap masing-masing butir pernyataan dengan rumus sebagai berikut:

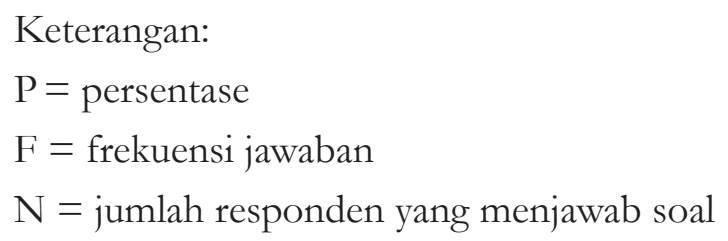

Hasil perhitungan keseluruhan dapat dilihat pada halaman lampiran. Di bawah ini penulis menjelaskan analisis dari perhitungan persentase jawaban berdasarkan masing-masing butir pernyataan:

a. Pada tabel pernyataan nomor 1 menunjukkan dengan menggunakan metode pembelajaran Example Non-Example siswa setuju karena lebih bersemangat mengikuti pelajaran yang menyatakan sebanyak 14 siswa (78\%), siswa yang menyatakan kurang setuju sebanyak 3 (17\%), dan siswa yang menyatakan tidak setuju sebanyak $1(6 \%)$. Berdasarkan data tersebut persentasenya adalah $78 \%$ / 14 siswa menyatakan guru selalu menggunakan metode pembelajaran Example Non Example ketika pembelajaran keterampilan menulis karangan. 17\% / 3 siswa menyatakan guru kadang-kadang menggunakan metode pembelajaran Example Non 
Example ketika pembelajaran keterampilan menulis karangan. $6 \% / 1$ siswa menyatakan guru tidak pernah menggunakan metode pembelajaran Example Non Example ketika pembelajaran keterampilan menulis karangan.

b. Pada tabel pernyataan nomor 2 menunjukkan dengan menggunakan metode pembelajaran Example Non Example siswa setuju bahwa kegiatan menulis adalah hal yang sangat menyenangkan sebanyak 7 siswa (39\%), siswa yang menyatakan kurang setuju sebanyak 8 siswa (44\%), dan siswa yang menyatakan tidak setuju sebanyak 3 siswa (17\%). Berdasarkan data tersebut diketahui persentasenya adalah 39\%/7 siswa selalu merasa senang ketika kegiatan menulis dengan menggunakan metode pembelajaran Example Non Example. 44\% / 8 siswa kadang-kadang merasa senang ketika kegiatan menulis menggunakan metode pembelajaran Example Non Example. 17\% / 7 siswa merasa tidak senang ketika kegiatan menulis dengan menggunakan metode pembelajaran Example Non Example.

c. Pada tabel nomor 3 menunjukkan dengan menggunakan metode pembelajaran Example Non Example siswa setuju karena lebih cepat paham dan lebih mudah dalam menyusun karangan sebanyak 14 siswa (78\%), siswa yang menyatakan kadang-kadang sebanyak 1 siswa (6\%), dan siswa yang menyatakan tidak pernah sebanyak 3 siswa (17\%). Bersadarkan data tersebut diketahui persentasenya adalah 78\% / 14 siswa merasa cepat paham dan mudah dalam menyusun karangan ketika guru menggunakan metode pembelajaran Example Non Example. 6\% / 1 siswa kadang-kadang merasa paham dan mudah ketika menyusun sebuah karangan ketika guru menggunakan metode pembelajaran Example Non Example. 17\% / 3 siswa merasa tidak paham dan sulit dalam menyusun sebuah karangan ketika guru menggunakan metode pembelajaran Example Non Example.

d. Pada tabel nomor 4 menunjukkan siswa setuju bahwa guru Bahasa Indonesia menjelaskan dan memberikan arahan sebelum mengerjakan sebanyak 12 siswa (67\%), siswa yang menyatakan kurang setuju sebanyak 4 siswa $(22 \%)$, dan siswa yang menyatakan kurang setuju sebanyak 2 siswa (11\%). Berdasarkan data tersebut diketahui persentasenya adalah $67 \%$ / 12 siswa menyatakan bahwa guru selalu menjelaskan dan memberikan arahan sebelum mengerjakan. 22\% / 4 siswa menyatakan kurang setuju karena guru tidak selalu memberikan penjelasan dan arahan ketika sebelum mengerjakan. 11\% / 2 siswa menyatakan tidak setuju karena guru tidak pernah memberikan penjelasan dan arahan sebelum mengerjakan.

e. Pada tabel pernyataan nomor 5 menunjukkan siswa setuju guru melakukan interaksi kepada siswa yang belum paham sebanyak 11 siswa (61\%), siswa yang menyatakan kurang setuju sebanyak 5 siswa (28\%), dan siswa yang menyatakan tidak setuju sebanyak 2 siswa (11\%). Berdasarkan data tersebut diketahui persentasenya adalah 61\% / 11 siswa menyatakan setuju 
karena guru selalu memberikan interaksi dan menjelaskan kepada siswa yang belum paham. 28\% / 5 siswa menyatakan kurang setuju karena guru jarang memberikan interaksi dan menjelaskan kepada siswa yang belum paham. 11\% / 2 siswa menyatakan tidak setuju karena guru tidak pernah memberikan interaksi ataupun arahan kepada siswa yang belum paham.

f. Pada tabel pernyataan nomor 6 menunjukkan siswa setuju metode pembelajaran Example Non Example yang digunakan oleh guru lebih mengenai sasaran tujuan pembelajaran dibandingakan metode konvensional sebanyak 11 siswa (61\%), siswa yang menyatakan kurang setuju sebanyak 5 siswa (28\%), dan siswa yang menyatakan tidak setuju sebanyak 2 siswa (11\%). Berdasarkan data tersebut diketahui persentasenya adalah 61\% / 11 siswa menyatakan setuju karena metode pembelajaran Example Non Example yang digunakan oleh guru lebih mengenai sasaran tujuan pembelajaran dibandingakan metode konvensional. 28\% / 5 siswa menyatakan kurang setuju karena metode pembelajaran Example Non Example yang digunakan oleh guru kurang mengenai sasaran tujuan pembelajaran dibandingakan metode konvensional. 11\% / 2 siswa menyatakan tidak setuju karena metode pembelajaran Example Non Example yang digunakan oleh guru tidak mengenai sasaran tujuan pembelajaran dibandingakan metode konvensional

g. Pada tabel pernyataan nomor 7 menunjukkan siswa setuju metode pembelajaran Example Non Example yang digunakan sesuai dengan materi yang diajarkan sebanyak 13 siswa $(72 \%)$, siswa yang menyatakan kurang setuju sebanyak 3 siswa $(17 \%)$, dan siswa yang menyatakan tidak setuju sebanyak 2 siswa (11\%). Berdasarkan data tersebut diketahui persentasenya adalah 72\% / 13 siswa setuju guru selalu menggunakan metode pembelajaran Example Non Example sesuai materi yang sedang dipelajari. 17\% / 3 siswa menyatakan kurang setuju karena guru jarang menggunakan metode pembelajaran Example Non Example yang sesuai dengan materi pembelajaran. 11\% / 2 siswa menyatakan tidak setuju karena guru tidak pernah menggunakan metode pembelajaran Example Non Example saat mengajar.

\section{2) Keterampilan Menulis Karangan MI Ma'arif Karanganyar}

Setelah dibuat statistik deskripsi tiap variabel, hasil jawaban responden variabel keterampilan menulis karangan secara keseluruhan kemudian dikategorikan menjadi tiga yaitu setuju, kurang setuju, tidak setuju. Pembagian kategori menggunakan rumus interval kelas yaitu nilai tertinggi ideal dikurangi nilai terendah ideal ditambah satu kemudian dibagi jumlah kelas.

Untuk mencari nilai tertinggi ideal yaitu jumlah angket dikalikan nilai jawaban 
tertinggi 30 dari jumlah angket 10x3. Sedangkan nilai ideal terendah yaitu hasil dari jumlah angket 10 dikalikan nilai jawaban terendah 10x1. Adapun rumusan tersebut antara lain:

$$
\begin{gathered}
\text { Interval }=\frac{(\text { nilai tertinggi }- \text { nilai terendah })+1}{\text { jumlah kelas }} \\
\frac{(30-10)+1}{3}=\frac{21}{3}=7
\end{gathered}
$$

Adapun hasil klasifikasi jawaban responden dapat dilihat dari tabel berikut:

\section{Tabel 4.4}

Kategori Variabel Keterampilan Menulis Karangan Mata Pelajaran Bahasa Indonesia Siswa MI Ma’arif Karanganyar

\begin{tabular}{ccccc}
\hline No & Nilai & Jumlah & Presentase & Kriteria \\
\hline 1 & $10-16$ & 1 & $6 \%$ & Kurang \\
2 & $17-23$ & 2 & $11 \%$ & Cukup \\
3 & $24-30$ & 15 & $83 \%$ & Baik \\
Jumlah & & 18 & $100 \%$ & \\
\hline
\end{tabular}

Berdasarkan distribusi frekuensi jawaban di atas tampak bahwa dari 18 responden, $6 \%$ siswa memiliki kemampuan keterampilan menulis karangan dalam kategori kurang, 11\% siswa memiliki kemampuan keterampilan menulis karangan dalam kategori cukup, dan $83 \%$ siswa memiliki kemampuan keterampilan menulis karangan dalam kategori baik. Angka tertinggi jawaban responden adalah kategori baik yang menunjukkan bahwa siswa memiliki kemampuan keterampilan menulis karangan yang baik. Distribusi jawaban responden tersebut dapat digambarkan sebagai berikut:

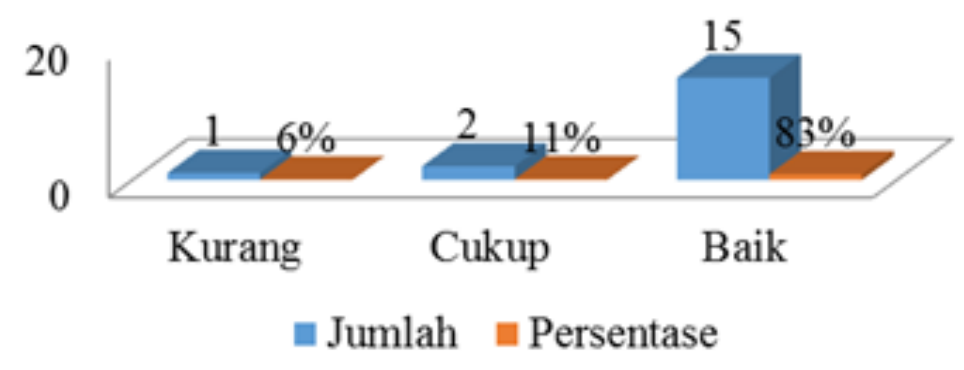

Grafik 4.2

Grafik Keterampilan Menulis Karangan 
Dari data hasil jawaban responden berdasarkan indikator variabel keterampilan menulis karangan yang dapat dilihat di halaman lampiran diadakan perhitungan persentase jawaban terhadap masing-masing butir pernyataan dengan rumus sebagai berikut:

\section{Keterangan:}

$\mathrm{P}=$ persentase

$\mathrm{F}=$ frekuensi jawaban

$\mathrm{N}=$ jumlah responden yang menjawab soal

Hasil penghitungan keseluruhan dapat dilihat pada halaman lampiran. Dari hasil observasi yang dilaksanakan dengan diberikan tugas menulis karangan dengan menggunakan bantuan media gambar, didapatkan data sebagai berikut:

a. Dilihat dari konsistensi bentuk/ ukuran/ porsi huruf pada tulisan siswa 14 siswa $(78 \%)$ sudah mampu menulis dengan baik yaitu sesuai dengan garis pada lembar jawab dan bentuk ukuran serta porsi huruf konsisten dan jelas. 3 siswa (17\%) sudah mampu menulis dengan cukup baik yaitu sesuai dengan garis pada lembar jawab akan tetapi masih terdapat bentuk, ukuran, dan porsi huruf yang kurang konsisten dan kurang jelas. 1 siswa $(6 \%)$ sudah mampu menulis akan tetapi masih banyak kekurangan karena masih belum sesuai dengan garis pada lembar jawab serta masih terdapat bentuk, ukuran, dan porsi huruf yang kurang konsisten dan kurang jelas.

b. Dilihat dari aspek jarak antar huruf dan kata pada tulisan siswa 13 siswa (72\%) sudah mampu menulis dengan jarak huruf dan kata baik dilihat dari hasil tulisan yang rapi dan tidak ada huruf yang bertumpuk pada setiap kata maupun kalimat. 3 siswa (17\%) sudah mampu menulis dengan jarak huruf dan kata yang cukup baik dilihat dari hasil tulisan yang cukup rapi akan tetapi masih terdapat huruf yang bertumbuk pada kata maupun kalimat. 2 siswa (11\%) sudah mampu menulis akan tetapi masih kurang baik karena tidak ada jarak antar kata dan masih terdapat banyak huruf yang bertumpuk.

c. Dilihat dari aspek posisi sikap duduk ketika melaksanakan kegiatan menulis 15 siswa (83\%) sudah duduk dengan baik dilihat dari saat melakukan kegiatan menulis posisi tubuh tegap. 2 siswa (11\%) sudah duduk dengan baik dan tegap akan tetapi sesekali kepalanya masih diletakkan diatas meja atau sambil tiduran. 1 siswa $(6 \%)$ posisi duduknya kurang baik karena posisi tubuhnya tidak tegap malah cenderung sering menulis dengan kepala di letakkan di atas meja atau sambl tiduran.

d. Dilihat dari aspek siswa yang hasil tulisannya rapi dan bersih 13 siswa $(72 \%)$ hasil tulisannya baik dilihat dari hasil tulisan yang rapi dan bersih 
dan tidak ada bekas kotor dari tulisan yang dihapus. 3 siswa (17\%) hasil tulisannya cukup baik dilihat dari kerapian dan kebersihan akan tetapi masih ada bekas tulisan yang dihapus dan terlihat sedikit kotor. 2 siswa (11\%) hasil tulisannya masih kurang baik dilihat dari hasil tulisan yang kurang rapi dan banyak bekas penghapus yang membuat kotor.

e. Dilhat dari aspek penulisan bentuk huruf yang jelas dan mudah dipahami 8 siswa (44\%) sudah mampu menulis dengan bentuk huruf jelas dilihat dari hasil tulisan yang baik dan penulisan hurufnya rapi dan jelas. 9 siswa $(50 \%)$ sudah mampu menulis dengan huruf yang jelas tetapi masih dijumpai sedikit cara penulisan huruf yang belum sesuai. 1 siswa $(6 \%)$ sudah mampu menulis akan tetapi hasil tulisannya kurang jelas dan penulisan hurufnya masih harus banyak belajar lagi.

f. Dilihat dari aspek semangat dan antusias dalam mengikuti kegiatan menulis 11 siswa (61\%) mengikuti kegiatan menulis dengan semangat dan antusias dapat dilihat ketika guru memberikan tugas kepada siswa dan siswa langsung mengerjakan dengan baik. 5 siswa (28\%) mengikuti dengan semangat dan antusias tetapi terkadang merasa bosan dan jenuh. 2 siswa (11\%) mengikuti kegiatan menulis dengan kurang semangat, dan justru malah terkadang tidak semangat di tunjukan dengan sikap dan hasil tulisannya.

g. Dilihat dari aspek ketepatan siswa ketika memilih kata (diksi) dalam menulis karangan 14 siswa (78\%) sudah tepat dan mampu memilih kata (diksi) dengan baik serta pengunaan kata penghubung ketika sedang melakukan kegiatan menulis juga sudah tepat. 2 siswa (11\%) sudah tepat dan mampu memilih kata (diksi) dengan baik akan tetapi masih kurang tepat dalam penggunaan kata penghubung dalam kegiatan keterampilan menulis karangan. 2 siswa (11\%) dalam pemilihan kata (diksi) dan kata penghubung yang digunakan siswa dalam menulis sebuah karangan masih kurang tepat dan masih ditemui kesalahan-kesalahan didalam hasil tulisan siswa tersebut.

h. Dilihat dari aspek cara menggunakan atau memegang pensil pada waktu melakukan kegiatan menulis 12 siswa (67\%) sudah baik dalam menggunakan dan memegang pensil ketika melakukan kegiatan menulis sehinnga siswa tidak merasa kelelahan. 5 siswa (28\%) sudah lumayan baik dalam menggunakan dan memegang pensil ketika melakukan kegiatan menulis akan tetapi kadang masih sedikit merasa kelelahan. 1 siswa $(6 \%)$ sering melakukan kesalahan ketika menggunakan dan memegang pensil ketika melakukan kegiatan menulis karangan sehingga siswa sering merasakan kelelahan dan mengakibatkan memakan banyak waktu untuk menyelesaikan hasil tulisan tersebut. 
i. Dilihat dari aspek cidera atau terjadi kelelahan pada siswa 15 siswa $(83 \%)$ saat kegiatan menulis sampai akhir pembelajaran tidak merasa kelelahan dilihat dari masih semangat dan tanggannya tidak merasa pegal. 3 siswa $(17 \%)$ saat kegiatan menulis sampai akhir pembelajaran siswa merasa lelah dan cidera.

\section{Pengujian Hipotesis}

Hipotesis yang diajukan dalam penelitian ini yaitu hubungan metode pembelajaran Example Non Example terhadap keterampilan menulis karangan. Untuk membuktikan kebenaran hipotesis tersebut, maka digunakan analisis korelasi product moment. Berdasarkan hasil analisis melalui program IBM SPSS 21 for windows, maka diperoleh hasil sebagai berikut:

\section{Tabel 4.5}

Hasil Analisis Korelasi

\begin{tabular}{|c|c|c|c|}
\hline \multicolumn{4}{|c|}{ Correlations } \\
\hline & & $\begin{array}{c}\text { Metode } \\
\text { Pembelajaran } \\
\text { Example Non } \\
\text { Example }\end{array}$ & $\begin{array}{c}\text { Keterampilan } \\
\text { Menulis Karangan }\end{array}$ \\
\hline \multirow[b]{2}{*}{$\begin{array}{l}\text { Metode Pembelajaran } \\
\text { Example Non Example }\end{array}$} & $\begin{array}{c}\text { Pearson } \\
\text { Correlation }\end{array}$ & 1 &, $735^{*+}$ \\
\hline & $\begin{array}{l}\text { Sig. } \\
\text { (2-tailed) }\end{array}$ & & ,001 \\
\hline \multirow{4}{*}{$\begin{array}{c}\text { Keterampilan Menulis } \\
\text { Karangan }\end{array}$} & $\mathbf{N}$ & 18 & 18 \\
\hline & $\begin{array}{l}\text { Pearson } \\
\text { Correlation }\end{array}$ &, $735^{* *}$ & 1 \\
\hline & $\begin{array}{c}\text { Sig. } \\
\text { (2-tailed) }\end{array}$ & ,001 & \\
\hline & $\mathbf{N}$ & 18 & 18 \\
\hline
\end{tabular}

Dari hasil uji korelasi product moment di atas nilai rxy yang diperoleh sebesar 0,735 angka indeks korelasi yang diperoleh tidak bertanda negatif. Ini berarti korelasi antara variabel X (metode pembelajaran Example Non Example) dan variabel Y (keterampilan menulis karangan dalam mata pelajaran bahasa Indonesia) terdapat korelasi positif diantara kedua variabel tersebut. Apabila nilai rxy yaitu 0,735 dibandingkan dengan nilai $\mathrm{r}$ tabel pada taraf signifikansi 5\% dengan $\mathrm{df}=\mathrm{N}$ $\mathrm{nr}=18-2=16$ diketahui $\mathrm{r}$ tabel yaitu 0,468 , maka rxy lebih besar dari $\mathrm{r}$ tabel sehingga Ha yang diajukan diterima, yang berarti ada korelasi positif antara metode pembelajaran example non example terhadap keterampilan menulis karangan dalam mata pelajaran bahasa Indonesia siswa kelas 5 MI Ma'arif Karanganyar. 
Metode pembelajaran merupakan salah satu faktor yang mempengaruhi proses belajar mengajar di Madrasah. Guru berusaha memahami karakteristik siswa untuk memilih metode pembelajaran yang sesuai dengan materi pembelajaran sehingga setiap siswa terlibat aktif dalam proses pembelajaran. Oleh karena itu pemilihan metode pembelajaran example non example dalam keterampilan menulis karangan yang dipilih oleh guru sudah tepat. Guru dan siswa bersama-sama mencapai tujuan pembelajaran yang diharapkan. Selain itu setiap siswa juga melakukan kegiatan untuk mencapai tujuan yang diharapkan. Dengan penggunaan metode pembelajaran example non example siswa terdorong lebih aktif dan bersemangat dalam melakukan kegiatan menulis sehingga kemampuan keterampilan menulis karangan siswa meningkat.

Dari hasil uji korelasi product moment diatas nilai rxy yang diperoleh sebesar 0.735, terletak antara 0.70-0.90 berdasarkan pedoman tabel fundamented Statistics in Psychology and Education yang dikutip oleh Sudijono (2008: 193) dapat dinyatakan bahwa kekuatan korelasi antara variabel metode pembelajaran example non example dan variabel keterampilan menulis karangan adalah korelasi yang tergolong tinggi atau kuat.

\section{KESIMPULAN}

Berdasarkan analisis dan pembahasan penelitian maka dapat diberikan kesimpulan sebagai berikut:

a. Penggunaan metode pembelajaran Example Non Example yang digunakan oleh guru kelas V MI Ma'arif Karanganyar dalam kategori cukup baik. Hal ini dapat dilihat dari nilai rata-rata 17,7 atau 18 yang termasuk dalam kategori baik.

b. Kemampuan keterampilan menulis karangan siswa kelas V MI Ma'arif Karanganyar setelah menggunakan metode pembelajaran Example Non Example termasuk dalam kategori baik. Hal ini dapat dilihat dari nilai rata-rata 23,5 atau 24 yang termasuk dalam kategori baik.

c. Ada hubungan penggunaan metode pembelajaran Example Non Example dengan keterampilan menulis karangan siswa kelas V di MI Ma'arif Karanganyar. Hal ini dibuktikan dengan perolehan nilai koefisien product moment sebesar 0.735 lebih besar dari $\mathrm{r}$ tabel 0.468 dengan $\mathrm{df}=\mathrm{N}-\mathrm{nr}=18-2=16$ pada taraf signifikansi $5 \%$. Dari uji korelasi product moment nilai rxy yang diperoleh sebesar 0.735 , yang terletak antara 0.70-0.90 dinyatakan bahwa kekuatan korelasi antara variabel metode pembelajaran example non example dan variabel keterampilan menulis karangan dalam mata pelajaran bahasa Indonesia di MI Ma'arif Karanganyar adalah korelasi yang tergolong tinggi dan kuat. 


\section{DAFTAR PUSTAKA}

Arikunto, Suharsimi. 2010. Manajemen Penelitian. Jakarta: Rineka Cipta.

Arikunto, Suharsimi. 2010. Prosedur Penelitian Suatu Pendekatan Praktik. Jakarta: Rineka Cipta.

Gulo, W. 2003. Metodologi Penelitian. Jakarta: Grasindo

Hastuti, Sri. 1984. Permasalahan dalam Bahasa Indonesia. Jakarta: Intan.

Huda, Miftahul. 2015. Model-Model Pengajaran Dan Pembelajaran: Isu-Isu Metodis Dan Paradigmatis. Yogyakarta: Pustaka Pelajar.

Iskandarwassid \& Dadang Sunendar. 2008. Strategi Pembelajaran Bahasa. Bandung: Remaja Rosdakarya.

Resmini, Novi dkk. 2006. Membaca Dan Menulis Di SD Teori dan Pengajarannya. Bandung: UPI Press.

Sabri, Ahmad. 2007. Strategi Belajar Mengajar Micro Teaching. Ciputat: Ciputat Press.

Saddhono, Kundharu \& Slamet. 2014. Pembelajaran Keterampilan Berbahasa Indonesia Teori dan Aplikasi. Yogyakarta: Graha Ilmu.

Sugiyono, 2015. Metode Penelitian \& Pengembangan: Research and Development. Bandung: Alfabeta.

Sungguh, As’ad. 2006. Ejaan Yang Disempurnakan. Jakarta: Bumi Aksara.

Suprijono, Agus. 2015. Cooperative Learning Teori dan Aplikasi Paikem. Yogyakarta: Pustaka Pelajar.

Tarigan, Henry Guntur. 2008. Menulis Sebagai Suatu Keterampilan Berbahasa. Bandung: Angkasa.

Widoyoko, Eko Putro. 2012. Teknik Penyusunan Instrumen Penelitian. Yogyakarta: Pustaka Pelajar.

Zubaidah, dkk. 2002. Bahasa dan Sastra Indonesia Kelas V SD/MI. Klaten: Sahabat. 